\title{
Karma and Corona: A Philosophical Perspective on COVID-19 As An Outcome of Cruelty Towards Animals By Humanity
}

\author{
Shanthi Van Zeebroeck \\ University of London, Arizona State University, Golden Gate University, Université Libre de \\ Bruxelles USA, Belgium \\ Corresponding Author: Shanthi Van Zeebroeck \\ E-mail: svanzeebroeck@gmail.com
}

\begin{abstract}
In the wake of a global pandemic called COVID-19, the world is enduring drastic human suffering in the form of deaths, draconian rules such as social-distancing, and country-wide lockdowns to combat this pandemic. What gave rise to this pandemic? This paper takes the position that COVID-19 is an outcome of cruelty committed by humans towards animals. In support of its position, this paper will make references to two Hindu cardinal laws, namely Paramātmā, and Karma, contained in the sacred Hindu epic, Bhagavad-Gita (the Gita).

This paper is presented in five parts. Section I will trace COVID-19's background. Section II will provide scientific proof that the pandemic originated in wildlife. In Section III, Zoonotic transfer from live animal markets as a source of infectious diseases will be explored. In Section IV, Karmic repercussions: The Hindu cardinal laws contained in The Gita will be explored. To this end, two Hindu cardinal laws, namely IV(A) Paramātmā, and IV(B) Karma will be discussed. In Section V, this paper will take the position that animal cruelty is the grossest kind of human ignorance, for which there are grave consequences. This paper will conclude that COVID-19 is an outcome for cruelty committed by humans towards animals, a response from the universe.

Key words: Karma, Corona, COVID-19, Animal Cruelty, Animals, Humanity.
\end{abstract}

Note: COVID-19, Pandemic, and virus will be used throughout the paper as transposable terms.

\section{Background}

The world watched in horror as COVID-19 devastated China in early December. After witnessing massive growth in human fatalities spreading from China to all over the world caused by COVID19, The World Health Organization (WHO) declared it to be a pathogenic pandemic on March 12 th, 2020 [1].

COVID-19 is a type of virus that has symptomatic characteristics of a common cold such as fever, dry cough, continuous cough, and in severe cases, respiratory complications. It is believed to have originated from animals, and is believed to be zoonotic, i.e. it was transmitted from animals to humans. It is believed to have originated from either a live animal market or a laboratory in Wuhan, Hubei province, in China and has, up to date, caused an epidemic growth in human fatalities worldwide.

\section{Scientific proof that COVID-19 originated in wildlife}

As the world tried to cope with, and contain the catastrophic pandemic, it also simultaneously wondered in perplexity as to how it all started, i.e. the origins of the pandemic. Multiple theories, 
some more conspiratorial than others, pointed its origins to a live animal market in Wuhan, a province in China, or that it may have been bioengineered in a laboratory in the same province, and that the virus infected humans, through an intermediary host animal. However, there is no confirmation from China as to the precise origin.

Nonetheless, this paper's research found an article published by The Lancet, in which 27 health scientists, from 9 countries, claimed, backed by reams of scientific proof, that the virus has a "natural origin," that it "originated in wildlife," and therefore, was not bioengineered.

Advocating full transparency, the health scientists claimed that the sources were researched by other health scientists, not only from China, but also "multiple countries," and they (the other health scientists) have analysed the genomes of the virus's causative agent, severe acute respiratory syndrome coronavirus 2 (SARS-CoV-2), and have found "overwhelming" conclusions that the virus "originated in wildlife [2].

If COVID-19 is a bat coronavirus, how did it infect humans? While initial research study results pointed to pangolins having a range between $85.5 \%$ and $92.4 \%$ genetic match to the virus, another study found the bat to have the closest match at 96\%, making COVID-19 a bat coronavirus [3].

If COVID-19 originated from a bat, how did it infect humans, resulting in a global pandemic today? Or more appropriately, how did humans get infected by bats? Whether an animal infected a human or a human infected himself/herself by coming into close contact with the virus was the question. It was clear, however, that it was not the bat's fault! As one scientific researcher, Sara Platto from Jianghan University in Wuhan astutely noted [4]:

"The problem is not the animals, it's that we get in contact with them,"

This paper takes the position that cruelty towards animals is the reason why humanity is facing a global pandemic.

\section{Zoonotic transfer from live animal markets as a source of infectious diseases}

Many articles traced COVID-19 to a live animal market in Huanan, a province in China. This paper will focus on one article that succinctly summarizes the human activities in these live animal markets that have caused the virus to spread from animals to humans. According to this article, COVID-19 transferred to humans through close contact with many different wild animals "being held together in confined spaces and small cages" [5]. This close contact was brought about by "a variety of human activities [that] allow for consistent and regular interaction" such as "hunting, butchering and farming (husbandry), as well as the global trade of animals and domestication of exotic animals as pets." It is no secret as to what happens in live animal markets. In these markets, animals face gruesome last moments in their lives before being mercilessly slaughtered for human consumption. Many mainstream media outlets have provided first-hand accounts of this practice. This paper chose two instances that follow:

In the first instance, a reporter for The National Review recounted:

"Terrified dogs and cats [are] crammed into rusty cages. Bats and scorpions [are] offered for sale as traditional medicine. Rabbits and ducks [are] slaughtered and skinned side by side on a stone floor covered with blood, filth, and animal remains." [6]

In the second instance, in The New York Post, the blood-spattered conditions in which the animals lived their last moments, side by side other dead and skinned animals, before being mercilessly slaughtered, was recounted by a reporter:

"In stall after stall, a mix of live and dead animals, which run the gamut from the known (pig, ox, duck, chicken) to the rare or unknown due to the condition of the carcass (,) stare back at you. In the wet areas of the market (,) usually reserved for fish and sea creatures and where the ground is slick with water and often blood (,) the stink is worse. The animals that have not yet been dispatched by the butcher's knife make desperate bids to escape by climbing on top of each other and flopping or jumping out of their containers (to no avail). At least in the wet areas, the animals don't make a sound. The screams from mammals and fowl are unbearable and heart-breaking." [7]

It is also important to note that while global pandemics such as SARS have also been linked to live animal markets in China, it is not the only country that maintains, and practices live animal 
markets. In fact, the concept of live animal markets is hardly a novel revelation, but an ancient practice. Many countries around the globe, have historically maintained live animal markets for centuries. They still do. In many cities in the USA, live animal markets are maintained. In Minnesota, a study was conducted that showed a connection between live animal markets maintained there and the zoonotic transfer of viruses to humans [8]. Other countries that maintain live animal markets include Ghana, Nigeria, Mexico and Brazil, Hong Kong, Singapore and Malaysia, among others.

The cruelty faced by animals in the last moments before they are slaughtered by humanity comes back as karmic repercussions to haunt humanity for inflicting pain on animals. Animals suffered, so now humans suffer, for what humans did to animals.

\section{Karmic repercussions: The Hindu cardinal laws contained in The Gita}

In Hinduism, one of the oldest religions in the world, animal cruelty is perceived as one of the grossest kinds of ignorance and will give rise to serious karmic repercussions for humanity. In order to explain these karmic repercussions, this paper will discuss the most important cardinal rule of Karma alongside Paramātmā, both contained in the Bhagavad-Gita (the Gita).

For the purpose of clarity, the Gita is a Hindu scripture that is part of the Hindu epic, Mahabharata (The Great Dynasty). In Mahabharata, the struggles between two groups of cousins, the Kauravas and the Pandavas, in the age of the Bharata dynasty is recounted. Mahabharata, along with Ramayana, forms the two great epics in Hindu philosophical history.

The Gita, also referred to as the "song of god," is a conversation between the Supreme Soul, Krishna, and a human warrior, Arjuna, who is one of the Pandava brothers. In a deeper sense, the conversation is about an inner conversation that a human being has during his life with his or her belief in a higher power, i.e. the universe.

Cruelty towards animals is strictly condemned in the Gita, due to the belief that all life is sacred. In fact, the Gita goes further in its condemnation of animal cruelty by stating that it is not only the grossest form of ignorance, but it summons grave karmic repercussions for the killer from the universe:

"Slaughtering poor animals is also due to the mode of ignorance. The animal killers do not know that in the future the animal will have a body suitable to kill them. That is the law of nature. In human society, if one kills a man he has to be hanged. That is the law of the state. Because of ignorance, people do not perceive that there is a complete state controlled by the Supreme Lord. Every living creature is the son of the Supreme Lord, and He does not tolerate even an ant's being killed. One has to pay for it. So, indulgence in animal killing for the taste of the tongue is the grossest kind of ignorance." Bhagavad Gita 14:16 [9].

In the above quote, Krishna warns that if we live in ignorance of a higher power, that exists in all living things, and continue to mercilessly slaughter animals, we will pay for our actions.

In addition, Krishna warns that in the law of a state (state here means the material realm), we have laws to charge a man for killing another man, but in the law of the state controlled by the Supreme Lord (state here refers to the metaphysical realm), there are additional laws. These are the laws of Paramātmā and Karma, which advocate that all lives are equal, and all laws are therefore equal.

\section{The Hindu cardinal law of Paramātmā}

In Gita, we learn that all life is sacred in the universe, because of a cardinal law, namely, the existence of the Paramātmā or the Supreme Soul.

In Chapter 5, Text 18, Krishna says:

The humble sages, by virtue of true knowledge, see with equal vision a learned and gentle brahmana, a cow, an elephant, a dog and a dog-eater [outcaste]. Bhagavad Gita 5:18 [9].

In essence, Krishna as the Supreme Soul teaches us that while we as bodies are material production of different modes of material nature, we as living bodies, have souls within these bodies. All living things, animals or humans come under the premise of these living bodies. While each living body has its own soul, it is the Supreme Soul that lives in all living bodies. In this sense, Krishna as the Supreme Soul lives in all of us, humans and animals, "without distinction." 
Therefore, we must treat each other with the due respect that we accord the Supreme Soul himself. It is due to this belief that Hindus accord animals equal respect and status as they would humans. It is due to this belief that they go further and accord the status of divinity to animals. Cruelty towards animals is seen as a grave sin, incurring grave karmic consequences in the cycle of samsara.

\section{The Hindu cardinal law of Karma in the cycle of Samsara}

The law that all life is sacred in the universe, because of the existence of a Supreme Soul is closely tied to another cardinal law, namely Karma. Karma does not simply mean action; it means more than that. Karma is an action that will always incur a reaction. If we commit bad actions such as rape, murder, we will incur bad reactions from the universe, such as life sentence and death penalty. If we commit good actions, such as engage in charitable activities or save someone's life from misery, we will incur good reactions such as good health, happiness, wealth, and beauty from the universe. Simply put, bad actions incur bad reactions. This is Karma.

The complexity about Karma is that these human actions, good or bad, and the ensuing reactions from the universe, good or bad, happen not in just one lifetime, but in multiple lifetimes. The karmic process in an ongoing and continuing process throughout the soul cleansing cycle (Samsara) of birth, life, death and rebirth (reincarnation), until the soul is cleansed of bad karma and attains Moksha (liberation of the soul) from material bondage to this world.

Following the laws of Paramātmā and Karma, then what has happened are actions so grave that they have incurred equally grave reactions from the universe in the form of a pandemic that is now causing an epidemic growth of human fatalities. This is the response from the universe churning out its own revenge on mankind, for treating animals with cruelty [9].

Conclusion: COVID-19 as a response from the universe on cruelty towards animals

"The greatness of a nation and its moral progress can be judged by the way its animals are treated." Mahatma Gandhi

We live in a world where there exists a profound form of human hypocrisy. While most of us advocate that all lives are equal, the reality is that all lives are not treated equal. Therefore, all laws are not equal pertaining to humans, and animals.

How can we protect animals from cruelty? Who speaks for these animals? Who speaks for living things that have no voice to speak for themselves? Where is justice for these animals? If we see the deadly effects of COVID-19 on the world, the universe has spoken for the animals, and has provided a voice for the voiceless. As mentioned in section III, humanity will suffer if it inflicts suffering on animals. The Hindu laws speak for themselves. This is a response from the universe, which is handing out its own justice for cruelty towards animals.

As of November 8th, 2020, the COVID-19 resource centre of The John Hopkins University of Medicine has registered 49,968,373 global cases of COVID-19, with global deaths registered at $1,252,427[10]$.

This is a massive number of global deaths that humanity can stop by preventing animal cruelty. There is hope, since animal activists and groups, including the Humane Society of the United States, People for the Ethical Treatment of Animals, and Animal Wellness Action, have started to pressure Asia, and other countries to stop the unsavory practices at live animal markets, and to close them completely [11].

In July 2020, in the state of Washington, a legal petition for rulemaking was filed with the U.S. Surgeon General to "shut down" live animal markets to prevent another zoonotic transfer and a global pandemic that could cost millions of lives worldwide [12].

The world is becoming aware of why we humanity is suffering through a global pandemic. COVID-19 is what humanity is paying for, in the form of deaths. for cruelty towards animals. The world has in fact noticed that maybe, this is a message from the universe.*

This is a massive number of global deaths that humanity can stop by preventing animal cruelty. There is hope, since animal activists and groups, including the Humane Society of the United States, People for the Ethical Treatment of Animals, and Animal Wellness Action, have started to 
pressure Asia, and other countries to stop the unsavory practices at live animal markets, and to close them completely.

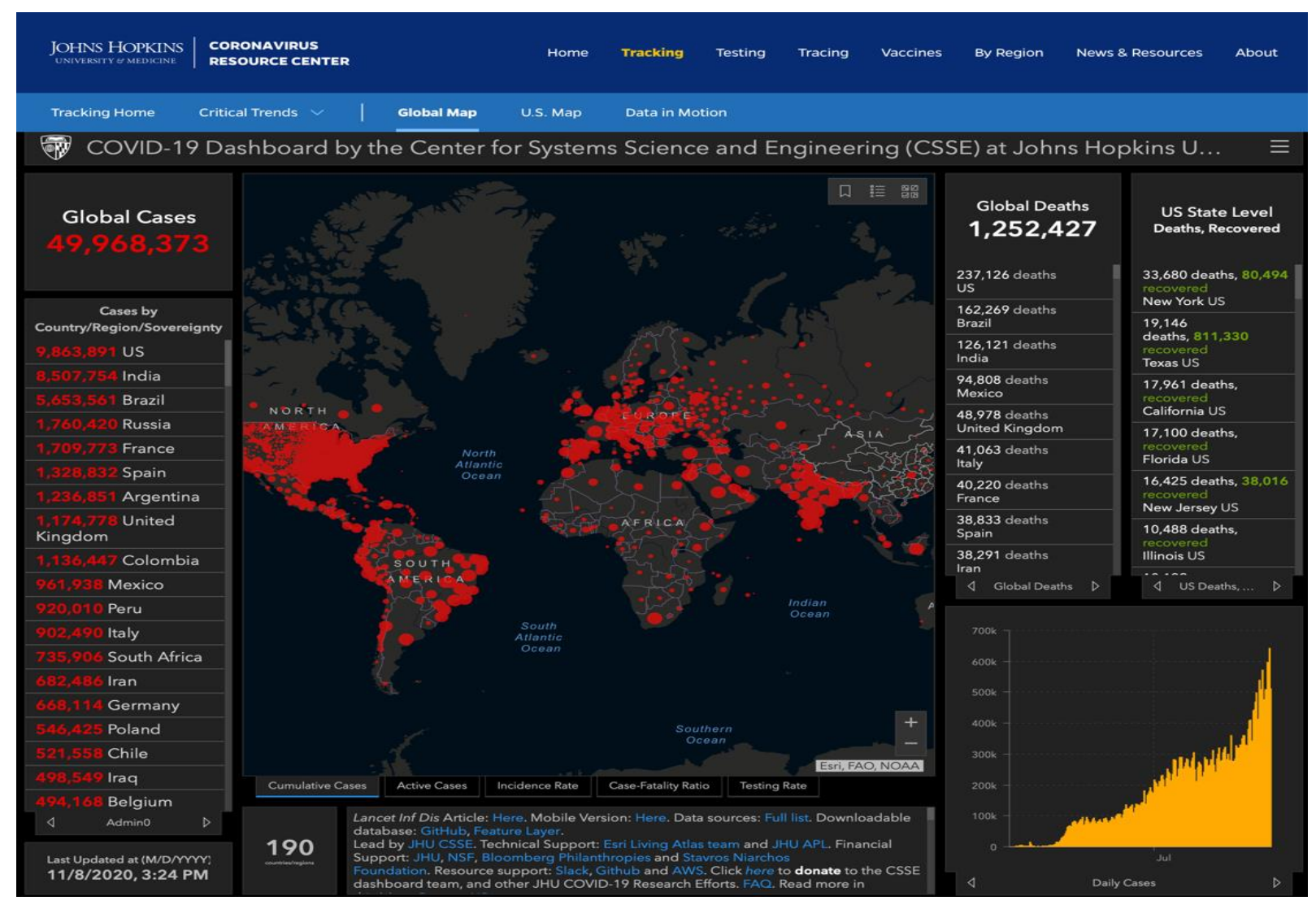

Figure 1

In July 2020, in the state of Washington, a legal petition for rulemaking was filed with the U.S. Surgeon General to "shut down" live animal markets to prevent another zoonotic transfer and a global pandemic that could cost millions of lives worldwide.

The world is becoming aware of why we humanity is suffering through a global pandemic. COVID-19 is what humanity is paying for, in the form of deaths. for cruelty towards animals. The world has in fact noticed that maybe, this is a message from the universe.*

*(In Hindu mythology, "Churning of the ocean of milk" is an expression to denote the perpetual battle between the devas or gods and the asuras or demons).

\section{REFERENCES}

1. WHO announces COVID-19 outbreak a pandemic. (2020, March 12). Retrieved March 17, 2020, from http://www.euro.who.int/en/health-topics/health-emergencies/coronavirus-covid19/news/news/2020/3/who-announces-covid-19-outbreak-a-pandemic2

2. Calisher C, Carroll D, Colwell R, Corley RB, Daszak P, Drosten C, Enjuanes L, Farrar J, Field H, Golding J, Gorbalenya A. Statement in support of the scientists, public health professionals, and medical professionals of China combatting COVID-19. The Lancet. 2020 Mar 7;395(10226):e42-3.

3. Zhou P, Yang XL, Wang XG, Hu B, Zhang L, Zhang W, Si HR, Zhu Y, Li B, Huang CL, Chen HD. A pneumonia outbreak associated with a new coronavirus of probable bat origin. Nature 2020;579(7798):270-3.

4. Cyranoski D. Mystery deepens over animal source of coronavirus. Nature 2020;579(7797):18-19. 
5. Jandu, N. (2020, September 06). Human activities are responsible for viruses crossing over from bats and causing pandemics like coronavirus. Retrieved November 05, 2020, from https://theconversation.com/human-activities-are-responsible-for-viruses-crossing-over-frombats-and-causing-pandemics-like-coronavirus-134226

6. Scully, M. (2020, April 15). China's Wet Markets, America's Factory Farming. Retrieved April 15, 2020, from https://www.nationalreview.com/2020/04/chinas-wet-markets-americas-factoryfarming-both-violate-moral-common-sense/

7. Froelich, P. (2020, January 25). Inside the horrific, inhumane animal markets behind pandemics like coronavirus. Retrieved April 15, 2020, from https://nypost.com/2020/01/25/inside-thehorrific-inhumane-animal-markets-behind-pandemics-like-coronavirus/

8. Choi MJ, Torremorell M, Bender JB, Smith K, Boxrud D, Ertl JR, Yang M, Suwannakarn K, Her D, Nguyen J, Uyeki TM. Live animal markets in Minnesota: a potential source for emergence of novel influenza A viruses and interspecies transmission. Clin Infect Dis 2015;61(9):1355-62.

9. Bhaktivedanta Book Trust. Bhagavad Gita As It Is: with the original Sanskrit text, roman transliteration, English equivalents, translation, and elaborate purports. Los Angeles; 1986.

10. Johns Hopkins Coronavirus Resource Center. (2020, Nov 8, 2020). Retrieved Nov 8, 2020, from https://coronavirus.jhu.edu/

11. Ani. (2020, April 7). Broad coalition forming in US to pressure China to close wet markets. Retrieved April 9, 2020, from https://www.business-standard.com/article/news-ani/broadcoalition-forming-in-us-to-pressure-china-to-close-wet-markets120040800021_1.html

12. Doctors Urge Surgeon General To Shut Down U.S. Live Animal Markets. (2020, July 4). Retrieved November 05, 2020, from https://www.pcrm.org/news/news-releases/doctors-urge-surgeongeneral-shut-down-us-live-animal-markets

Acknowledgements: Nil

Funding: Nil

Conflict of interest: Nil 